\title{
Management of Financial Support for Electric Power Infrastructure under Conditions of Economic Crisis
}

\author{
Nikolay Kuznetsov \\ Candidate of Technical Sciences, Head of Innovative Development Administration, Financial University under the Government of \\ the Russian Federation; Email: nkuznetsov@outlook.com
}

\section{Doi:10.5901/mjss.2015.v6n5s2p372}

\section{Abstract}

One of the leading branches of the Russian industry is one of the largest electric power industries of the world. To a large extent, the state of the country's electric power sector defines the competitiveness and internal potential of the growth of the whole Russian economy, its largest part consisting of energy-consuming branches. The aim of this article is to develop recommendations on managing financial support for infrastructure projects under the conditions of crisis phenomena and taking into account tendencies of development in the Russian electric power industry. The results of the study undertaken herein allow to make the conclusion that the electric power industry continues functioning under difficult economic conditions. Restricted opportunities for attracting financing in combination with the proficit of electric energy and the highest level of power supply network amortization bring grand-scale challenges for all members of the industry. Urgent tasks of managing enterprises working in the electric energy sector include searches for additional financial sources for modernizing and renewing the industry infrastructure facilities.

Keywords: electric power industry, power resources, investments, investment attractiveness, financial resources, modernization, infrastructure.

\section{Introduction}

Generation of electric power, transmission and allocation of power resources are an integral part of any modern economy. Stable generation of electric power, systems of power transmission and allocation gain more prominence in the contemporary world due to the climate change and closer integration between systems of neighboring countries (Hammons, 2011).

The Russia electric power industry is an integral part of the national fuel and power industry and is the basic industry of the modern economy. In addition to providing private households with electric power, technologically modern and reliable electric power industry contributes to economic development of the country, strengthening of social climate in the country, and increasing of Russian manufacturers' competitiveness. In addition to its role of the energy source, electric power sector contributes to the uplift of general economic activity and occupation through capital investments in the electric power infrastructure (International Russia Renewable Energy Program. Regional Renewable Energy Tariffs in Russia, 2013).

It is known that electric power supply system cannot function without a relevant infrastructure including numerous companies of various kinds of ownership, and various levels of regulation and control. Efficiency and reliability of the whole electric power system depends on how the transmission networks work today and how they will develop in the long-term run (Volk, 2013).

At the same time the industry development is restrained by a number of problems. The basic one includes the deficiency of investment resources with simultaneous growth of expenses. The main source of these problems is a clamorous requirement of financial nature - to suppress the current expenses to the prejudice of the infrastructure development and capital investment. As a consequence we have an ageing infrastructure of electric power industry; its personnel and organizational structure cease to meet today's needs and opportunities.

Capital investments in electric power industry are defined by several factors including steady growth of electric power consumption, ageing of existing infrastructure utilities, reliability of supplies and the necessity to decrease $\mathrm{CO} 2$ emissions while generating electric power. In this context the deficiency of capacities may seem more significant, therefore it will be necessary to take timely measures. Replacement of ageing electric generating stations will not only provide stability and reliability of electric power supply but will also allow to decrease production expenses due to using more modern and efficient technologies (KPMG, 2011). 
One of the basic tasks of structural reforms carried out in the electric power industry was to attract private capital for renewing fixed assets and improving technical state of the production complex capacities in order to raise economic indicators of its functioning.

However, experience of implementing investment projects in the Russian electric power industry shows that the basic source of their financing includes funds from the federal budget. The difficulty of inflow of private investments in the industry is partially related to the difficult economic situation, and partially to the delay of selling generating assets to private investors (Kuznetsov, 2014).

At the same time it is obvious that budgetary funds are not sufficient for investing in the construction of new facilities of the electric power industry infrastructure and modernization of the existing ones.

Thus, at the present time it is urgent to study processes of financial security of the electric energy infrastructure.

\section{Methodology}

The aim of this research is to develop recommendations on managing financial security of infrastructure projects in the Russian electric power industry under the conditions of crisis phenomena and taking into account current tendencies.

The subject of the research is a combination of management relations arising during the implementation of infrastructure projects that stipulate the investment attractiveness and financing of enterprises of the electric power industry and as a result define real dynamics and direction of the production process in the Russian electric power industry.

In order to achieve the set aim, it is necessary to successively solve the following tasks:

- To regard the dynamics of the Russian electric power industry development under conditions of financial and economic crisis and post-crisis period,

- To research the state of the infrastructure of the electric power industry and define the needs in investments for creating new production capacities and modernizing the current ones,

- To develop practical recommendations on improving financial security of infrastructure facilities in the Russian electric power industry.

This work is based on methodological approaches that provide system study of problems related to enterprises working in the electric power industry, and their investment strategies. In this research various methods and tools of scientific cognition were used, including methods of system and statistical analysis, analogues, comparative analysis, monographic research, and graphic method.

Informative and empiric basis of this article includes legislative and statutory instruments of the Russian Federation, statistic indicators of the Federal Service of State Statistics of the Russian Federation, analytic materials of the Ministry of Energy of the Russian Federation and industry reviews of Russian and foreign information agencies, etc.

\subsection{Post-event Analysis of the Electric Power Industry Development}

In the 2000s of the XX century when the Russian government actively increased control at strategic sectors such as oil, gas, metals, the electric power industry underwent momentous reforms aiming to liberalize and privatize it (INFOLine, 2014).

Traditionally the electric power industry was thought to be a naturally monopoly sector and was cultic in the Soviet economy. Much money was invested in it until mid-1980-ies. Then the volume of capital and exploitation expenses for its infrastructure started considerably decreasing, and had been practically nullified by 1990 .

As a whole, the retrospective dynamics of the Russian economy electric capacity trace two phases stipulated by transformation processes during the transfer to the market economy model.

After the collapse of the Soviet Union, the generating capacities exceeded the demand due to the GDP decrease. A sharp decline in the production caused a considerable growth of production industries' electric capacity: for the period of 1990-1995 this indicator increased 1.4 times.

However, in 1999 production growth started and demand for energy increased. Though, the growth of GDP outran the similar indicator of general electric power consumption with the result that the indicator of the Russian GDP electric capacity gradually decreased up to 2008 (Figure 1). 


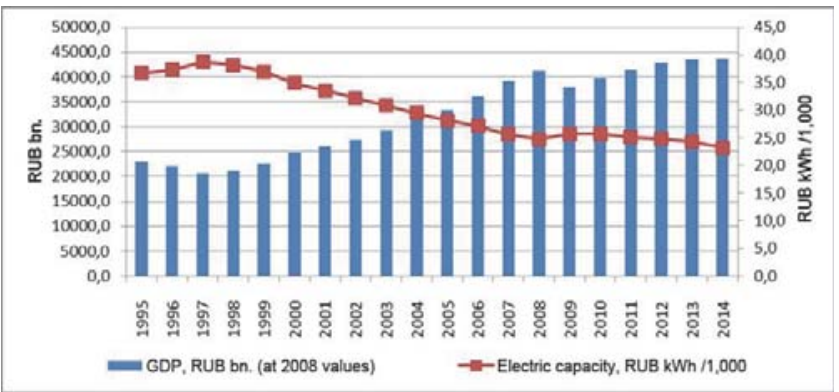

Figure 1. Dynamics of the Russian GDP Electric Capacity 1995-2014 (Federal State Statistics Service of the Russian Federation, 2014)

In 1999-2008 an unsteady increase in the volumes of electric power consumption took place in the context of rather high rate of the Russian economy growth. In 2009 due to the economic crisis, the economy and consequently electric power consumption ceased (Figure 2).

The structural reform in the electric power industry in 2001-2009 aimed to provide financing for the industry by attracting private investors (both homeland and foreign) for constructing new facilities and modernizing the current ones, and to implement market principles of price formation in relation to the supplied electric energy in the industry. As a result of this reform and fundamental changes, the industry managed to improve technical state of capacities of the production complex of the electric power industry, and to increase economic indicators of its functioning.

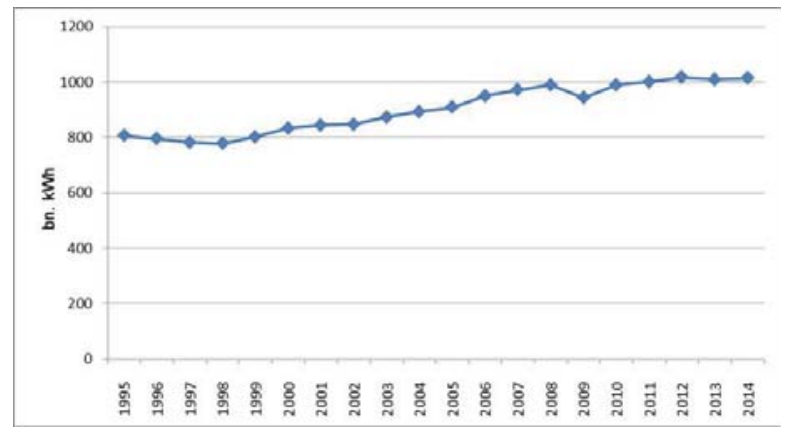

Figure 2. Dynamics of Electric Power Consumption in the Russian Federation in 1995-2014, bn. kWh

Russian electric power companies, both private and state, overcame the crisis of 2008-2009 rather successfully - as a whole, even better that a lot of world and leading companies.

For example, in 2009 in spite of the total decrease in macroeconomic indicators in the Russian Federation, the income of 10 largest companies increased by 13\%, and EBITDA by 28\% (Kiseleva and Petruhin, 2012). On the whole, supporting electric power companies also showed positive result. Above all, dynamic growth of prices and tariffs for electric energy contributed to it. It allowed companies to compensate losses from the decrease in electric power consumption in the economy and increase in prices for energy sources.

At the same time the economic crisis showed global problems in the Russian electric energy complex that brewed in the industry during the previous years. A number of power supply companies including guaranteeing suppliers (GS) accumulated considerable debts. Basically these debts were owned to distribution companies for transmitting electric power through networks that had resulted from payment failure by final customers.

1. Debts receivable of organizations from the "Generation, Transmission, Allocation and Sale of Energy Power" group as on January 1, 2014 was RUB 1,252 bn (+32\% as on 01.01.2011), including RUB 199 bn of the overdue one (+61\% as on 01.01.2011). Herewith, for the considered period debts receivable increased by 1.4 times (by 2 times for the overdue one) according to "electric power generation" subsection, by $3 \%$ (by $36 \%$ 
for the overdue one) according to "electric power transmission"), 4.7 times (3.8 times for the overdue one) according to "electric power sale"). The debts receivable related to "electric power allocation" decreased by $53 \%$ (by $79 \%$ for the overdue one). It is necessary to note that according to "electric power generation" above 95\% of the overdue debts receivable accounts for CHP (amounts also include debts for heat energy) (Analysis Report, Ways of Strengthening Payment Discipline Among Electric Power Consumers, 2014).

At the present time obvious leaders are found in the industry. They demonstrate high level of steadiness to various crisis phenomena. They include large network companies as well as OJSC "RusHydro" and OJSC "Rosenergo Atom Concern". Their high steadiness is stipulated, first of all, by practically full independence from prices for power resources and low level of debt load. So, for example, the relation of net debt to EBITDA in OJSC "RusHydro" is 1.48 as on the end of 2013.

In addition, their strategic importance for the industry and participation of the state in their capitals intensify the bargaining position while agreeing tariff solutions and accepting regulatory acts, and in some cases provide direct financing of investment programs.

On the other hand, the whole group of companies with relatively high risks is found in the industry. They are support energy companies that have considerably lower profitability but at the same time have a higher debt load in comparison with generating companies. As compared to 2008, their debt load has considerably increased both due to the profitability decrease and the necessity to attract borrowings for implementing investment programs on CSA (Capacity Supply Agreement).

Their risks are also intensified by the fact that unlike other industries where companies can individually make decisions about freezing investment programs in case of a crisis, the interruption of CSA projects is to be approved by the state. Otherwise, companies have to pay fines for the refusal or untimely supply of the capacity (up to $25 \%$ of the investment project value).

\subsection{Current State of the Infrastructure and Investments in Electricity Generation Facilities}

The current functioning of the electric power system of the Russian Federation is based on the combination of technological and commercial infrastructure controlled by the state, on the one hand, and companies interrelating with each other in the competitive environment and generating and selling electric energy, on the other hand.

Organizations of technological infrastructure include the company managing the unified national electric network (OJSC "Federal Network Company"), the company performing operator management (OJSC "System Operator of the Unified Energy System"), and interregional distribution grid companies (IDGC).

The commercial infrastructure includes OJSC "Trading System Administrator" and its subsidiary OJSC "Financial Calculations Center". The activity of infrastructure organizations, including price formation and creating terms and conditions of interrelation with contractors, is to be regulated by the state.

The structure of the Russian Unified Energy System (UES) includes 7 united energy systems (East, Siberia, Ural, mid-Volga region, South, Center and North-West) that include 69 regional energy systems.

The electric energy complex of the UES of Russia consists of 700 electric generating stations each of which has a capacity of more than 5 megawatt. As on 01.01 .2015 the total installed capacity of all electric generating stations of Russia was above 232.45 thous. megawatt: $68 \%$ - combined heat plants (CHP), 21\% - hydroelectric generating stations (HEP), and $11 \%$ - nuclear thermal power stations (NPS).

Starting since 2009, the installed capacity and volumes of the electric generation in Russia have been consistently growing (Table 1).

Table 1. Basic Operating Data of the Electric Power Industry for 2008-2014 (Functional Report of the UES of Russia, 2014)

\begin{tabular}{|l|c|c|c|c|c|c|c|}
\hline Indicator & 2008 & 2009 & 2010 & 2011 & 2012 & 2013 & 2014 \\
\hline Capacity, thous. MW & 216.09 & 211.85 & 214.87 & 218.24 & 223.07 & 226.47 & 232.45 \\
\hline Electric power production, bn. kWh & $1,023.4$ & 957.1 & $1,004.72$ & $1,019.40$ & 1032.3 & $1,023.50$ & $1,024.9$ \\
\hline Load peak, MW & 151,133 & 150,012 & 149,157 & 147,769 & 157,425 & 147,046 & 154,709 \\
\hline Electric power consumption, bn. kWh & $1,006.56$ & 942.8 & 988.96 & $1,000.10$ & 1016.5 & $1,009.80$ & $1,013.9$ \\
\hline
\end{tabular}

So, as compared to the 2009 crisis, the installed capacities increased by $9.7 \%$, and the electric generation increased by $7 \%$ and reached the indicator of $1,024.9 \mathrm{bn}$. $\mathrm{kWh}$ for the same period. In 2014 the excess of the maximum capacity 
consumption over the indicators achieved in 2013 was fixed in 49 electric power systems. At the present time the installed capacity of the electric power system in terms of electric power generation exceeds the maximum consumption of the capacity 1.55 times. According to the results of 2014, the generation of electric power within the Russian unified energy system exceeded its consumption by $1.1 \%$.

The excess of electric power generation over the demand is moderate. It says about an economic efficiency of power supply. However, the capacity utilization factor (CUF) of CHP and HEP is on a rather low level. According to the results of 2014, it is $48.6 \%$ and $40 \%$ accordingly (in 2013 these indicators were $49.9 \%$ and $43.1 \%$, respectively) (Development of Power Generating Industry in Russia, 2014).

7,296.1 megawatt of new capacities were introduced in 2014. It exceeds the level of 20095.8 times. Due to the modernization, 398.53 megawatt of electric power capacities was introduced. It is 3.7 times more than in 2009. Table 2 shows the dynamics of indicators of the installed capacity of the Russian electric power industry in 2008-2014.

Table 2. Dynamics of Capacity Indicators of the Electric Power Industry of the Russian Federation in 2008-2014

\begin{tabular}{|l|c|c|c|c|c|c|c|}
\hline & 2008 & 2009 & 2010 & 2011 & 2012 & 2013 & 2014 \\
\hline New capacity introduction MW & $1,321.9$ & $1,268.40$ & $2,886.20$ & $4,688.30$ & $6,134.31$ & $3,738.37$ & $7,296.31$ \\
\hline Capacity increase due modernization & 412.4 & 108.9 & 291.9 & 219 & 339.09 & 253.6 & 398.53 \\
\hline Out-of-commission & $1,074.3$ & 287.7 & $1,006.70$ & $1,507.20$ & $1,911.37$ & 684 & $1,762.6$ \\
\hline Renewal coefficient & 0.008 & 0.007 & 0.015 & 0.022 & 0.029 & 0.018 & 0.033 \\
\hline Retirement rate & 0.005 & 0.001 & 0.005 & 0.007 & 0.009 & 0.003 & 0.008 \\
\hline
\end{tabular}

Almost all installed base of generating capacities has been here since the Soviet times and will be completely torn in several years. The state of electric power infrastructure is ageing and needs to be replaced and modernized.

So, at the present time the Russian Federation exploits one of the largest and simultaneously one of the oldest HEP in the world (Figure 3).

Underinvestment in the 1990s and 2000s also had a negative impact on the physical state of power equipment and constructions. It creates risks for the security of energy supply especially power supply as well as for its competitiveness and safety, whereas technical re-equipment and modernization of capital assets can increase the lifespan.

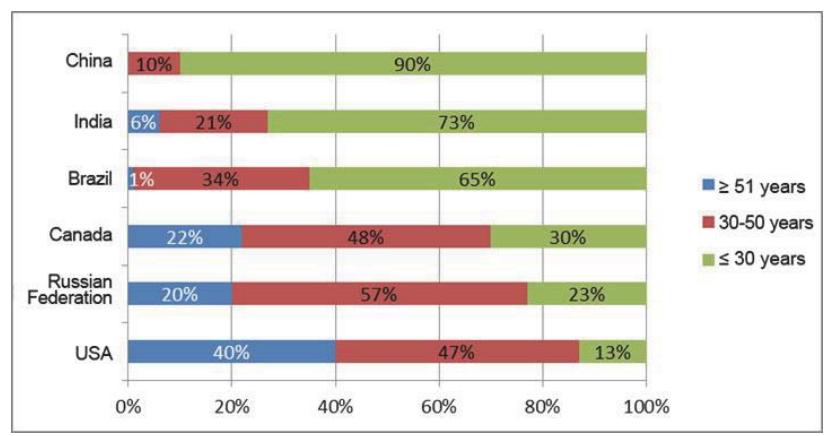

Figure 3. Age of HEP in the Russian Federation and in the World (Rushydro, 2015)

In many respects changes in the industry structure in 2008-2014 stipulated real investment attractiveness of specific enterprises that secure the industry functioning at the stage of generation, mainline and local transportation of electric energy and power supply and repair (Gibadullin, 2014).

The Russian power generating industry is not included in the list of facilities that are top priority for foreign resources investments. Foreign investors characterize it as the one with moderate, a little lower than the medium, investment attractiveness. Such estimation is stipulated, above all, by investment opportunities of foreign companies in the industry that are focused in the generation area while at the present time the network complex of receiving funds for the electric energy in calculations with consumers is the most attractive for investments (Popova, 2014).

In 2013 investments in the Russian electric power industry were RUB 867 bn, in 2012 - RUB 851 bn., in 2011 RUB 958 bn, and in 2010 - 811 bn. However, in 2014 investments in the industry decreased by 5.5\% as compared to 
2013 and were RUB $819 \mathrm{bn}$. This is the lowest indicator since 2010. This indicator is considerably lower than the target one established by the Ministry of Energy at the beginning of 2014. Investments in the generation development decreased by $4.7 \%$, down to RUB 497.7 bn, and by $6.7 \%$, down to RUB 321.7 bn in the integrated power grid.

The investment attractiveness of the industry remains on a low level due to the decrease in the capitalization of a number of key players, and deficit of efficient market mechanisms of attracting investments in the industry (Nuclear Project Financing Considerations for Goldman Sachs Russia, 2014).

JSC "FGC UES" had basic negative impact on the capitalization of the electric power index. So, for example, the market capitalization of "FGC UES" that is a system forming organization in the electric power industry and one of strategic enterprises of Russia has been sweepingly falling since 2010: in 2011 this indicator was on the level of RUB 351.16 bn, in 2012 - RUB 253.9 bn., and in 2013 - RUB 114.6 bn. As on 30.09.2014 the company capitalization decreased 1.6 times more and reached RUB 71.95 bn. (Financial data of JSC "FGC UES", 2014).

The increase in prices for equipment and costliness of credit resources in the context of the decrease in power consumption and worsening of the payment discipline in the industry make energy companies correct investment programs.

\subsection{Directions of Financial Support for the Electric Power Infrastructure}

Today, on the one hand, the Russian electric power industry is influenced by strict tariff regulation. On the other hand, it must perform its obligations to the state both on developing new capacities and providing consumers with reliable power supply. Return of invested funds and securing the growth of the business value are a separate challenge under terms and conditions of the current restrictions for private investors ("Analysis of Results of the Reform Related to Electric power industry and Proposals on Its Efficiency Growth" Analytical Report, 2013). Today companies that provide Russian cities and towns with centralized heat and water supply have similar problems.

It is necessary to note that at the present time the most important problem to be immediately solved is the energy consumption of the Russian economy. In relation to Western countries, it is 2-3 times higher than the similar indicator of Western countries. It requires a number of processes. The first one includes modernization and renewal of capital assets. The wear of networks is above $50 \%$, and achieves $70-80 \%$ for specific types of equipment. Of course, it is necessary to secure reliable functioning of the network electric power economy and its active renewal.

The results of 2014 revealed difficulties of the target financing of investment programs related to modernization and renewal of facilities including by virtue of calculating changes of initial value of projects, arrears of terms of equipment supply, and inefficient organizational work.

The basic problems in the area of investments management and the ones that restrain the industry investment programs on the modernization and renewal of the electric power infrastructure include:

1) Deficit of the investment resource that restricts opportunities on the project profile of certain companies and compels them, above all, to finance obligations.

2) Restrictions for tariffs growth. After the decision to freeze tariffs in 2014 , a lot of electric power companies faced the problem of deficit of financial resources for implementing investment projects and focused their attention on the growth of operational activity efficiency, its optimization and increase in efficiency of labor.

3) High debt load of electric power enterprises.

There is a big differentiation on collecting payments for electric power among the population in various regions of the country and within one region. It is caused both by objective reasons (for example, difference in the level of population's incomes) and the ones that arouse due to ineffective work of specific power supply and management companies involved in collecting payment for power supply.

It is necessary to reconsider the system of state control if not particularly to change the system of financial settlements between the market members, and the very principle related to the organization of interrelations between contractors in this strategically important area.

4) Restricted access to financing remains one of the basic challenges.

Insufficient financing is allocated for the measures that aim to increase energy efficiency and modernize electric power industry. Private banks still do not provide services specially developed for investing in power effective measures in industrial and housing sectors.

In accordance with the Russian Energy Strategy up to 2030, strategic aims of electric power industry include the following:

maintenance of reliable energy security on the national and regional levels;

- providing competitiveness of the price for electric power that makes it available for population and corporate 
sector; herewith, the price for electric power must be formed on the basis of the market principles of price formation and secure real payout of investment resources in relation to the industry;

- priority of requirements on regularity and reliability of supplying facilities and territories with electric power, regardless of the mode of their functioning (both in the normal mode and the ones characteristic of emergency situations); and

- providing innovation renewal of the sectoral operating process that aims to secure system growth of energy, ecological, and economic efficiency of the processes that support the formation of the sectoral chain of value (Russian Energy Strategy for the period up to 2030, 2009).

A number of the following key measures can contribute to an increase in financial support for projects related to the development of the electric power infrastructure and stimulation of investments in the industry development (Russia2014, 2014):

\subsubsection{Regulated tariffs, subsidizing, and cross-subsidization.}

The decrease in the demand for electric power, worsening of the price environment, inflation pressure, limitations for the growth of tariffs for housing and public utilities, growth of intraindustry competition will have a dramatic impact on financial stability of utilities and technical and economic parameters of the generation facilities.

In order to increase the competitiveness of the Russian industry, the Government of the Russian Federation must develop measures on reducing operating costs. Moreover, heat supply, electric power and gas sectors still have crosssubsidization. The Government of the Russian Federation is developing a required package of measures to cease this practice. Cancellation of subsidies and cross-subsidization is the most important measure for eliminating the violations of the market balance. It will allow market mechanisms to stimulate economic growth and change the consumers' behavior.

The problem of cross-subsidization can be solved through increasing the efficiency of operational and investment activity of network companies, excluding the required gross revenue of network companies that predominantly serve one consumer from the boiler tariff formation, and compensating a part of shortfall in income of territorial network organizations at the expense of the regional budget. According to the Minister, this is the way to provide equal allocation of the load for power network organizations, population and regional budget.

\subsubsection{Strengthening of payment discipline.}

Regions use various methods to increase consumers' payment discipline. On the level of the Federation objects, guaranteeing suppliers regularly publish a list of debtors and black lists of suppliers of resources for services of housing and public utilities. On the local level various ways of stimulating the improvement of the payment discipline - from warning to full disconnection from electric power - are applied.

At the present time the Ministry of Energy prepared proposals on establishing the standard in the amount of 1/130 of the refinancing rate for payments arrear. It will allow to exclude the motivation of non-payments and crediting electric power resources by non-payment for the resources that are consumed. Besides, the Ministry of Energy developed a procedure of obligatory financial guarantee for so called non-disconnectable consumers that violate the financial discipline of payments. This circumstance can be applied to consumers only in case of violating the payment discipline, and in this term the Government of the Russian Federation will establish the procedure (Bill No. 348213, 2013).

\subsubsection{Stimulation of investment activity in the electric power industry.}

The system of following methods and tools will allow to achieve a considerable potential of the investment attractiveness of the industry utilities:

- Feed-in tariff - either an established tariff that does not depend on the existing price levels of the wholesale electricity market or an extra charge to the wholesale market price. It is established for 15-20 years,

- Preferences for alternative electric power supply: tax stimulation (decrease of the tax rate, release from its payment),

- Cheap state crediting (subsidization) for acquiring and installing RES equipment,

- System of obligatory quoting (i.e. the one of the percent correlation of the electric power - traditional and RESbased - supplied to the market and established by the state). 


\section{Conclusion}

A lot of negative factors have an impact on today's electric power industry of Russia including unstable macroeconomic situation, worsening of payment discipline of contractors, considerable growth of the value of debt capital, etc. Ageing infrastructure especially in the electric power industry and the centralized heat supply require urgent investments. Reforms of the electric power industry that have been carried out in Russia since 2002 have contributed to forming the competitive market of the electric energy and inflow of investments, although not in the volume required for efficient modernization of this industry.

The basic task of managing enterprise of the electric power industry is to search for additional financial resources for modernization and renewal of the industry infrastructure facilities. It is necessary to regard on the level of the state the issue on accepting a complex of measures on correcting the policy and reforms aiming to stimulate investments in the electric energy infrastructure, including immediate refusal from cross-subsidization and gradual cancellation of subsidies, alleviation of access to financial resources, and applying relevant tax incentives.

\section{References}

Electricity Infrastructures in the Global Marketplace (2011, pp. 834, Hammons. T.J., Ed.). InTech. ISBN 978-953-307-155-8

International Russia Renewable Energy Program. Regional Renewable Energy Tariffs in Russia. 2013. International Finance Corporation. World Bank Group (2013). Retrieved from http://www.ifc.org/wps/wcm/connect/bfc20b8040c77040ae2fbf5d948a4a 50/Regional+tariffs+report Eng.pdf?MOD=AJPERES

Volk, D. (2013). Electricity Networks: Infrastructure and Operations Too complex for a resource? (pp.113). International Energy Agency.

KPMG. Perspectives of Power Generation Industry in Europe in relation to Credit Organizations (2011). Retrieved from http://www.kpmg. com/RU/ru/lssuesAndInsights/ArticlesPublications/Documents/ S_PU_1r.pdf

Kuznetsov, N.V. (2014). Financial support for Russia Utilities in the Context of Implementing Industry Development Programs. Fundamental Research, 8-6, 1431-1438.

INFOLine. Engineering in Electrical Energy Industry of the Russian Federation. Tendencies of 2014. Predictive Information up to 2020. The Largest Contractors of the Electric Power Construction Market. Retrieved from http://marketing.rbc.ru/research/56294 9992445506.shtml

Federal State Statistics Service of the Russian Federation. Retrieved from http://www.gks.ru/wps/wcm/connect/rosstat_main/ rosstat/ru/statistics/accounts

Kiseleva, E., Petrukhin, A. (2012). Russian Electrical Energy Industry: "Venture" for Private Investors. Retrieved from http://www. strategy.ru/UserFiles/File/Strategy.ru/russian-power-a-venture-for-investors.pdf

Analysis Report. Ways of Strengthening Payment Discipline among Electric Power Consumers. Analytical Center Affiliated to the Government of the Russian Federation.

Report about Functioning of Russian UES in 2014. JSC "SO UPS". Retrieved from http://so-ups.ru/ fileadmin/files/company/reports/ disclosure/2015/ups_rep2014.pdf

Development of Electrical Energy Industry in Russia for 2014. National Rating Agency. Retrieved from http://www.bigpowernews rul photos/0/0_4AUaYYUIQFqlJHeCrajNrLUucP4LGPko.pdf

Rushydro. Analyst's and Investor's Day. April 13, 2015. Moscow. Official website of RusHydro, Retrieved from http://www.rushydro.ru/ upload/iblock/b03/RusHydro_Apr_2014_Investor_day_RUS.pdf

Gibadullin, I.A. (2014). Basic Directions of Electric Power Industry Development. Science Studies, 2. Retrieved from http://naukovedenie. ru/PDF/05EVN214.pdf

Popova, E.A. (2014). Ways of Increasing the Efficiency of the Investment Policy at Utilities (thesis of Candidate of Economic Sciences: 08.00.05, pp. 91). KUBSAU, Krasnodar.

Nuclear Project Financing Considerations For Goldman Sachs Russia. June 2014. - "Financing Projects on Constructing NPS" Materials of Round-table Conference. Official website of JSCo. Retrieved from http://2014.atomexpo.ru/congress/materials/5

Financial Data of JSC "FGC UES". Official portal of JSC "FGC UES". Retrieved from http://www.fsk-ees.ru/shareholders_and_ investors/financial_information

"Analysis of Results of the Reform Related to Electrical Energy Industry and Proposals on Its Efficiency Growth" Analytical Report (2013). Moscow: Natural Monopolies Problems Institute. Retrieved from http://www.ruscable.ru/other/2 _05_2013_power_ reform_analysis.pdf

Russian Energy Strategy for the Period up to 2030. Approved by Order of the Government of the Russian Federation dated 13.11.2009 No. 1715-p. Retrieved from http://www.atominfo.ru/files/strateg/strateg.htm

Russia-2014. Synopsis. Detailed Review of Energy Politics. International Energy Agency. Retrieved from http://www.minenergo.gov.ru/ upload/iblock/b24/b246bf7457b13b61ad00aee463531723.pdf

"On Amending Specific Enactments due to Strengthening Payment Discipline of Energy Sources Consumers" Bill No. 348213-6. Official portal of the State Duma Committee for Energy. Retrieved from http://www.komitet2-13.km.duma.gov.ru/site.xp/053053049.html 